native occupation ; and further land is to be purchased out of moneys to be provided by Parliament. Purchase will be spread over a period of five years, the total amount of the expenditure being $£ 10,000,000$. This will admit, it is expected, of an addition of $14,000,000$ acres to the reserves. Among the provisions of the Bill it is proposed to include the gradual abolition of native squatting on European-owned lands and the registration of native labour tenants. of these the former will in all probability arouse some opposition on the part of various interests; but the practice has given rise to friction and abuse on occasion, and on the whole its abolition is probably well advised.

\section{Control of Australian Aborigines}

As innovation of no little importance in the method of controlling the Australian aborigines, who come under the jurisdiction of the Commonwealth Government, is announced from Canberra. The Cabinet has decided, it is reported by The Times correspondent in the issue of April 29, that in future the work of the police patrol in the south-west of the Northern Territory will be entrusted to an anthropologist who is familiar with the language and customs of the tribes. The district under the new officer will thus include the country of the Arunta, made famous in the annals of anthropology by the investigations of Sir Baldwin Spencer and F. J. Gillen. This change in administrative machinery is, no doubt, in large measure due to the protests made, especially by anthropologists, when recently certain aborigines were tried for murder on account of killings in accordance with tribal custom. It is, at any rate, regarded as marking an advance in the method of dealing with native offences against the law of the white man, as the officer will have magisterial powers to deal with the great majority of cases, and will take only the more important to the court at Alice Springs. Mr. Paterson, the Minister for the Interior, has announced that Dr. Strehlow of the University of Adelaide, now conducting investigations on behalf of that University in North Australia, has been appointed to the post.

\section{Scientific Research in Australia and New Zealand}

AT the instance of the Governments of Australia and New Zealand, steps are being taken to effect close collaboration between their respective Councils for Scientific and Industrial Research. The two Dominions have in common many problems in primary industry, and united action to solve them is obviously desirable. It is proposed to attach New Zealand officers to the Australian teams working on (a) mammitis in dairy cattle, (b) bovine contagious abortion, $(c)$ sterility in sheep and $(d)$ preservation and transport of foodstuffs. Australia will probably second an officer to the staff of the Dairy Research Institute of New Zealand, and will send the leaders of its Soils and Forest Products Divisions to consult with their corresponding numbers there about future co-operative organisation. This move for closer association between the research councils of the Dominions is overdue and its development will be watched with much interest.

\section{The Parliamentary Science Committee}

DURING the past twelve months several institutions have affiliated with the Parliamentary Science Committee; and the approximate aggregate membership of all the bodies affiliated is now 100,000. Two of the latest bodies to enrol themselves are the Institution of Gas Engineers and the British Association of Zoologists. The last-named accession affords peculiar satisfaction to the Committee, inasmuch as it is the first enrolment of a body devoted to pure $\rightarrow$ as distinct from applied-science; and it is hoped that it is the harbinger of others to come. Many societies devoted to natural history were perturbed last year at the prospect of a bombing centre being established near Chesil Beach. Letters of protest were published in the daily Press, but more effective action might have been taken by bringing the matter before Parliament through such a medium as the Parliamentary Science Committee, which actually meets at the House of Commons. By so doing, naturalists would have had the advantage of common action on their behalf by a Committee entitled to speak for an aggregate of 100,000 people interested in scientific matters - a body not to be lightly disregarded by a House of Commons the individual members of which owe their presence in that assembly to the votes cast in their favour.

\section{Physics of the Divining Rod}

Tнस April number of Discovery contains an article on the divining rod by E. Christie which gives a detailed account of methods adopted by the author in searching for water and certain metals. It claims to show that there is nothing mysterious about the power of divining, and that it is subject to definite natural laws. The great difficulty which impedes the progress of scientific investigation is that the statements of dowsers regarding their methods in the field and manner of inference vary considerably, and the article mentioned only adds yet another to the many already published. That there is a basic similarity cannot be denied by anyone who has taken the trouble to study them, but the elucidation of the fundamental facts from what are necessarily very subjective accounts has so far not been achieved. The author, however, is right in stressing the point that without examining the details, in such accounts as he has written, no man of science is likely to arrange a reliable test for dowsers. Experiments in which the underlying physical process is unknown are always difficult to interpret, and it is very doubtful whether a conclusive proof of the claims of dowsers will be obtained unless much more attention is given to their writings, vitiated as they nearly always are, by the incorrect use of the terminology of physies.

\section{Royal Institution: Annual Meeting}

THE annual meeting of the members of the Royal Institution was held on Friday, May 1. In the unavoidable absence of the president, Lord Eustace Percy, the chair was taken by the treasurer, Sir Robert Robertson. The Committee of Visitors, in a preface to its annual report, which was presented at 
the meeting, referred to the loss the Institution had sustained by the lamented death of its patron, His Majesty King George V. At a recent general monthly meeting it was announced that His Majesty King Edward VIII had been graciously pleased to grant his patronage to the Institution. The Visitors' Report referred to the increased attendance at the lectures of late. The recent course of Christmas Juvenile Lectures, given by Dr. Kenneth Mees on Photography, had an average audience of 515, and a Friday Evening Discourse given by Sir James Jeans on November 29 had an attendance of 640 , the largest at the Institution for many years. The Dewar research fellowship, set up under the will of the late Lady Dewar, has been filled by the appointment of Mr. A. R. Ubbelohde, lately senior scholar of Christ Church, Oxford, as the first Dewar fellow. Mr. Ubbelohde has begun investigations on the changes in the palladium lattice caused by the presence of hydrogen, as measured by X-rays, and on the latent heat of sublimation of chain compounds.

PART of the Brown legacy of between $£ 25,000$ and

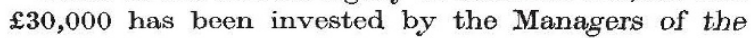
Royal Institution in the purchase of the freehold of No. 19, Albemarle Street, immediately adjoining the premises of the Institution. The purchase has been made in anticipation of future expansion of the research and other activities; but for the present, only the top two floors of the house have been occupied for Institution purposes. The remainder is being let on lease. The reconstruction of the principal library and the rooms below, which the Managers were compelled to undertake last year, is still in progress; and is expected to be completed during the summer. The large new research laboratory in the basement, the construction of which has been made possible by these alterations, promises to be a most valuable improvement. During the year, the publication by the Institution of "Faraday's Diary" has been completed by the issue of vol. 7 and a separate index volume. The Treasurer's report and accounts show a sound and satisfactory position, with substantial additions to the funds during the year despite the heavy cost of the library reconstruction scheme. This reconstruction has caused an interruption in the research work in progress with the large $\mathbf{5 0} \mathrm{kva}$. X-ray generator; but in other researches there has been considerable progress, as the report of the Committee of the Davy Faraday Research Laboratory shows. X-ray structure determinations, related chemical and magnetic problems, the optical study of methane, the construction of a hydrogen liquefier and the ether drift experiment are some of the experimental investigations referred to in the report. The following officers were elected for the year 1936-37 : President, Lord Eustace Percy; Treasurer, Sir Robert Robertson; Secretary, Major Charles E. S. Phillips.

\section{Salaries in the Civil Service}

AT the annual general meeting of the Institution of Professional Civil Servants held on April 30, the president, Sir Richard Redmayne, referred to the inadequacy of the remuneration of the highest posts in the specialist departments of the Civil Service. $\mathrm{He}$ directed attention to the recommendations made by the Royal Commission in 1931 that a salary of $£ 2,500$ should be paid to the Engineer-in-Chief in the Post Office, and that there should be "a certain number of posts carrying an inclusive salary of $£ 2,000$ a year", and to the fact that these recommendations have not yet been carried into effect. $\mathrm{He}$ also pointed out that the Committee on the Staffs of Government Scientific Establishments in 1930 commented on the inadequacy of the prospects offered for the higher posts in the scientific establish. ments, and recommended that a small ad hoc com. mittee should be appointed to consider these posts. In spite of this recommendation no action has been taken. Sir Richard claimed that the placing of the directing posts in the professional, scientific and technical departments on some degree of equality of status and remuneration with those obtaining on the non. technical side of the Service would conduce to that greater efficiency of the Service, which it is the primary aim of the Institution to promote. Sir Richard referred to the recent vote in the House of Commons on the question of equal pay for equal work as between men and women. He stated that the Institution is an unqualified supporter of the principle of equality.

\section{Rockefeller Foundation and International Health}

THe annual report for 1934 of the International Health Division of the Rockefeller Foundation, recently issued, gives an account of the world-wide activities of the Foundation in the field of public health. The projects in operation for which grants are made are broadly speaking of three types : (1) the control of specific diseases, (2) aid to Governments to establish public health on a permanent basis, and (3) public health education. Under the first-named, investigations upon the control of yellow fever have resulted in the discovery in South America of a type of rural or jungle yellow fever, which differs from the usual form in that it is not conveyed by the yellow fever mosquito, which is completely absent in such districts. How this form of yellow fever is conveyed to man is at present unknown. Malaria, hookworm disease, yaws, diphtheria and tuberculosis are some of the other diseases that are the subject of investigation. Foundation aid has been granted to the Bureau of Hygiene and Tropical Diseases of the British Colonial Office, to the Irish Free State and to the United Provinces, India, for local health ser. vices, and to the Calcutta school of public health. The total expenditure for the year amounted to $2,433,535$ dollars. The volume is illustrated with a number of interesting plates.

\section{Recent Acquisitions at the Geological Survey and Museum}

THE gemstone collections of the Geological Survey and Museum have been recently enriched by a number of valuable presentations by H.M. Queen Mary. These include a large polished and carved block of yellow amber weighing 26 ounces, probably from the Prussian coast of the Baltic Sea; an exceptionally 